\title{
A Study of Ethnoastronomy in Ciptagelar Civilizations, Sukabumi Regency, West Java, Indonesia: Relation of Full Moon Phase with Javanese Calendar and Hijriyah Calendar
}

\author{
Dewi Muthia ${ }^{1, *}$, Aprilia $^{1}$ \\ ${ }^{1}$ Astronomy Division, Faculty of Mathematics and Natural Sciences, Institut Teknologi Bandung, Jl. \\ Ganesa 10, Bandung, 40132, Indonesia
}

\begin{abstract}
Astronomy has been practiced for as long as humans have been looking at the sky. Early civilizations used several celestial objects to do their daily activities, like doing a traditional ceremony. Ciptagelar Village is located at Sukabumi Regency, West Java, Indonesia. It has been established for almost 650 years. Ciptagelar villagers consider that a full Moon phase is a special and sacred thing. They have a welcoming ceremony for it, named Mapag Purnama. We study this activity in the way of Ethnoastronomy. The methods that we used are interviewing the villagers, including the customary leader of Ciptagelar Village, and doing a literature study. Ceremony of Mapag Purnama is held every $13^{\text {rd }}$ to the night of $14^{\text {th }}$ of the Moon Javanese Calendar. We use three references for choosing the date of full Moon phase, namely Fred Espenak, NASA, and Stellarium application. This date is then converted from Solar Calendar to Javanese and Hijriyah. Because Javanese Calendar is adopted from Hijriyah Calendar, both of two will have the same dates. We use 120-years correction for a difference cycle and number of leap years. However, after $2010 \mathrm{CE}$ this correction is no longer valid. We find that the Javanese Calendar is one day slower than the Hijriyah Calendar.
\end{abstract}

\section{Introduction}

Indonesia is an archipelago. It has many islands as well as ethnicity and culture. In this modern era, it turns out that there are still a number of ethnic groups whom uphold their customs until now. One of them is the Ciptagelar Civilization which we study in this paper. They are located in Sukabumi Regency, West Java, Indonesia.

We conduct this research because of three motivations. First, we like a science that has a direct relation to the civilizations. We choose to study the ethnoastronomy in this way. "Ethnoastronomy is the study of astronomies of different races, people or ancient cultures which includes folk or indigenous astronomies, calendars, celestial lore, sky mythology and related ritual, cosmological concepts and celestial-related traditions of all people and cultures." [1]. We try to understand how science affects their lives. Second, Indonesia is a

\footnotetext{
* Corresponding author: mthdw788@gmail.com
} 
country that is suitable for doing an ethnoastronomy research. So many islands and differences in each ethnicity we can observe. Indonesia has an abundance of nature and culture.

Civilizations use many signs in nature to assist their daily activities $[4,5,6,7,8,11]$. One of them is related to astronomy, i.e. they have seen the sky and used several celestial objects to help them know about time to work, to farm, etc. Each ethnicity has a unique traditional ceremony related to observing the sky. Why then do we choose to study the Ciptagelar civilization than other civilizations in Indonesia? This question asks whether the third thing that motivates us. That is because Ciptagelar civilization is an unique civilization than others. What makes them unique? As we knew about customary civilizations, they tend to be backward, closed, and rarely want to accept technology, but this is different with Ciptagelar civilizations. Indeed, they are a customary civilization, but they live in an advanced village that is very open to the outside world and technology savvy.

The Ciptagelar villagers have several kinds of ceremonies. A few ceremonies are related to astronomy knowledge. One of them is Malam Opat Belasan. This name is taken from the Sundanese language and means a ceremony that held in every $13^{\text {rd }}$ to the night of $14^{\text {th }}$ in Javanese Lunar Calendar. This ceremony is conducted to welcome the full Moon phase. Thus, in Sundanese this ceremony also called Mapag Purnama.

\section{Method}

This research uses some methods to collect the data. First, we conduct a direct interview with the villagers and the customary leader of the Ciptagelar Village. Second, we conduct a literature study. To do the interview, we have to prepare the three steps, i.e. the preparation, the interview, and the post interview [9, 10]. For the preparation, we have to contact the villagers for asking permission related to their willingness to be interviewed. Then, if they are willing, we propose our arrival date to conduct the interview process. Then, we have to prepare the questions that will be asked to them in the interview. We also have to make sure our belongings that will be brought to their village and funds needed during the research.

The next step is about the interview. In this step, we just have to do well the interview process with questions that already prepared before. We also documented it during the interview. The last step is the post interview. In this step, we thanked the interviewees for their willingness to be interviewed. We also ask them about a possibility to conduct a further interview if needed.

\section{The Ceremony of Opat Belasan}

This ceremony is intended to welcome the full Moon phase. This ceremony aims to preserve ancestral traditions and mysteries. In Indonesian, it is referred to as wangsit from the ancestors to the customary leader of Ciptagelar Village. This ceremony enlivened by many art performances, such as Angling Dogdog Lojor, Topeng Kolot, Wayang Golek Rurukan, Jipeng, and Degung Gonjringan. The interesting thing about the art performance of Wayang Golek Rurukan is the story of the ancestors $[13,16,17,18]$. The Ciptagelar Villagers carried out this ceremony in the customary building, i.e. Imah Gede. This building is also the house of the customary leader, named Abah Ugi. 


\section{The Javanese Calendar System}

The Javanese Calendar has been used since 1600s CE. The Javanese Calendar is the result of an assimilation of the Indian Calendar, named Saka Calendar and Hijriyah (Islamic) Calendar. In the Javanese Calendar, the year numbering continues the year number of the Saka Calendar, the date and month are derived from the Hijriyah Calendar. Thus, in 1633 $\mathrm{CE}$, the Javanese Calendar has a year number of 1555 Java instead of 1043 Hijriyah (H) [14].

The Javanese Calendar has its own system of cycles. The two longest unit of time in Javanese Calendar are wind $u$ and lambang. Both of them have the same duration, i.e. eight years, but they have a different cycle. The total cycle of lambang is 16 years that is divided into two kinds of lambang, i.e. langkir and kulawu. For windu, it has a total cycle of 32 years that is divided into four kinds of windu, i.e. adi, kuntara, sengara, and sancaya.

From lambang and windu, there are eight kinds of year, i.e. Alip (354 days), Ehe (355 days), Jimawal (354 days), Je (354 days), Dal (355 days), Be (354 days), Wawu (354 days), and Jimakir (355 days). The Javanese have two kinds of calendar systems, i.e. the Pranata Mangsa (Solar Calendar) and the Lunar Calendar. This eight-year cycle is only for the Javanese Lunar Calendar. The $2^{\text {nd }}, 5^{\text {th }}$, and $8^{\text {th }}$ year are categorized as a leap year where a year consists of 355 days [3]. The additional day for the leap year is added to the $12^{\text {th }}$ month. The name and duration for each month on the Moon Javanese Calendar can be seen in the Table 1 below.

Table 1. The Name of Months in the Moon Javanese Calendar and their Duration.

\begin{tabular}{|c|c|c|}
\hline No. & Name of Months & Duration (days) \\
\hline 1. & Sura & 30 \\
\hline 2. & Sapar & 29 \\
\hline 3. & Mulud & 30 \\
\hline 4. & Bakda Mulud & 29 \\
\hline 5. & Jumadilawal & 29 \\
\hline 6. & Jumadilakir & 30 \\
\hline 7. & Rejeb & 29 \\
\hline 8. & Ruwah & 30 \\
\hline 9. & Pasa & 29 \\
\hline 10. & Sawal & 30 \\
\hline 11. & Sela & Besar 30 \\
\hline 12. & & \\
\hline
\end{tabular}


In the Javanese Calendar, there are the terms Pancawara and Saptawara. Both of them are unit of time for the week. Pancawara consists of five days, namely Legi, Pahing, Pon, Wage, and Kliwon, while Saptawara consists of seven days, namely Ahad, Senin, Selasa, Rabu, Kamis, Jum'at and Sabtu. Both run concurrently and are known as Pasaran in Javanese. Besides Pancawara and Saptawara, there are still six other kinds of Pasaran, i.e. Dwiwara (2 days), Triwara (3 days), Caturwara (4 days), Sadwara (6 days), Astawara (8 days), and Sangawara (9 days). Also, in the Javanese Calendar, there is another unit of time that is a combination of Pancawara and Saptawara namely Wuku. Each type of Wuku will change every week which consists of seven days.

The first month in the Javanese Calendar is Sura, thus first Sura is the beginning of the Javanese Calendar year. To decide this beginning of the year, the Javanese Calendar follows the Hijriyah Calendar year. Thus, first Sura coincides with first Muharram (the first month in Hijriyah Calendar).

\section{The Determination of the Date of Occurrence of the Full Moon Phase and Its Relation to the Ceremony of Malam Opat Belasan}

Ciptagelar villagers have their own perception about full Moon phase. Based on their opinion, a full Moon phase is something sacred. We know that Ciptagelar villagers have a ceremony that relates to the full Moon phase, namely Malam Opat Belasan. It is held every the $13^{\text {rd }}$ to the night of $14^{\text {th }}$ every month in the Moon Javanese Calendar.

When we interviewed one of the Ciptagelar villagers named Mr. Yoyo, he told that the ceremony of Malam Opat Belasan has two rituals. The first ritual is held at the night of the full Moon phase and the second is held after that full Moon phase. Also, he said that determining the date for the occurrence of the full Moon phase was based on the first experience of their ancestors who saw the full Moon phase in $1368 \mathrm{CE}$. That year, their ancestors saw the full Moon phase on the $13^{\text {rd }}$ to the night of $14^{\text {th }}$ in the Javanese Lunar Calendar. Accordingly, this date is set as the date of the full Moon phase in the Javanese Calendar. Until now, this date has been used as a celebration for the ceremony of Malam Opat Belasan.

To confirm Mr. Yoyo's explanation, we trace back the date and check whether it is true or not. To do so, we convert that date from the Western Calendar (in this case the Julian Calendar) to the Javanese Lunar Calendar. There are two ways to perform the conversion. First, we convert directly from the Gregorian Solar Calendar to the Hijriyah Calendar using the Hisab Urfi Calculation. Then, we use the year number in the Hijriyah calendar to obtain the year number in the Javanese Lunar Calendar. The other method is to convert the date from the Gregorian Solar Calendar to the Hijriyah Calendar then change the year number to the Javanese Lunar Calendar, and then apply the 120-year correction between the Javanese and Hijriyah Calendar.

\section{Hisab Urfi Islamic Dating System}

There are many types of Islamic Dating System, such as Hisab Hakiki, and Imkan Rukyat, but for this conversion, we will use the Hisab Urfi dating system. This dating system uses the Synodic cycle (based on observations) of Moon on average, i.e. 29 days, 12 hours, 44 minutes, and 2.8 seconds in every month as a reference calculation. This value is a time duration from one conjunction to another. Initially, the dating system began when the hijrah (moving from one place to another) event of the Prophet Muhammad SAW from Mecca to Medina that occurred on $15^{\text {th }}$ or $16^{\text {th }}$ of July 622 CE. 
The determination of the beginning of the month is based on hilal (thin crescent Moon) observation that can be seen after the Sunset. Hisab Urfi Islamic dating system is based on calculation. It means that it tends to predict rather than observe in determining something (for example, an astronomical phenomenon). A year consists of 12 months and each month consists of 29 days (for even months) or 30 days (for odd months). The names of the 12 months are Muharram, Safar, Rabi'ul Awal, Rabi'ul Akhir, Jumadil Awal, Jumadil Akhir, Rajab, Shakban, Ramadhan, Syawal, Zulkaidah, and Zulhijah [12].

The Hisab Urfi Islamic dating system has 30-year cycle. It contains of 11 leap years and 19 non-leap years. For leap years, a year consists of 355 days and the additional day is in the $12^{\text {th }}$ month. Leap years are assigned by dividing the year number by 30 and taking the remainder. Years with a remainder of 2, 5, 7, 10, 13, 15 (or 16), 18, 21, 24, 26, or 29 are leap years [2]. In addition, there is a correction approximately every about 2347-solar years between Hisab Urfi Islamic and the Gregorian Calendar because the Hisab Urfi Islamic Calendar is one day faster than the Gregorian Calendar.

\section{A 120-Year Correction}

Although the Javanese Lunar Calendar has the same first date as the Hisab Urfi Islamic Calendar, the year numbering is different. In addition, they are not always synchronised. For 30 years, Javanese Lunar Calendar consists of 10,631.25 days and Hijriyah Calendar consists of 10,631 days. For 60 years, Javanese Lunar Calendar consists of 21,262.5 days and Hijriyah Calendar consists of 21,262 days. For 120 years, Javanese Lunar Calendar consists of 42,525 days and Hijriyah Calendar consists of 42,524 days. Thus, there is an additional correction every 120 years.

\subsection{Date Conversion from the Solar to Javanese Calendar}

To convert dates in the Western Calendar (Julian Calendar) to the Javanese Lunar Calendar, we calculate the difference in days between the date we want to convert and a reference date, $\Delta \mathrm{H}$. The first date is the start of the Hijriyah Calendar, i.e. Muharram $1^{\text {st }} 1 \mathrm{H}$ or July $15^{\text {th }}$ or $16^{\text {th }} 622$ CE (we choose July $16^{\text {th }}$ ). This simplifies the conversion because the Hijriyah Calendar is related to the Javanese Lunar Calendar. The second reference date is July $16^{\text {th }}$, $1368 \mathrm{CE}$, being in the year that the ancestors of Ciptagelar civilization first saw the full Moon phase which falls on $14^{\text {th }}$ each month. The date we want to convert can be located between the two reference dates or outside of both. We can choose the date from three references, i.e. Espenak, National Aeronautics and Space Administration (NASA), and Stellarium application. Full Moon dates from Stellarium will be the date where the moon has the brightest apparent magnitude. Details of this conversion are in Diagram 1.

Diagram 1. The Calculation Scheme

July $16^{\text {th }} 622 \mathrm{CE}=$

Muharram $1^{\text {st }} 1 \mathrm{H}$

July $16^{\text {th }} 1368$ CE

\section{-}

○

\section{○}

The date we

want to

convert 


\subsubsection{Date Conversion with the Hisab Urfi Approach}

To conduct the conversion, we have to calculate $\Delta \mathrm{H}$ at first, then treat it in the framework of Hisab Urfi Islmaic dating system. The details are as follows:

-The date we want to convert: July $1^{\text {st }}, 1368 \mathrm{CE}$

-Visual apparent magnitude of the Moon: -12.40 $\Delta \mathrm{H}:$

Number of days between July $16^{\text {th }} 622$ CE and July $1^{\text {st }}, 1368$ CE in the Solar Calendar,

$\Delta \mathrm{H}=(1368 \mathrm{CE}-622 \mathrm{CE})-\left(\Delta\right.$ days between July $1^{\text {st }}, 1368 \mathrm{CE}$ and July $\left.16^{\text {th }}, 1368 \mathrm{CE}\right)$

$$
=746 \text { years- } 15 \text { days }=(746 \times 365.25) \text { days- } 15 \text { days }=272,461.5 \text { days }
$$

Number of days between July $16^{\text {th }}, 622$ CE and July $1^{\text {st }}, 1368$ CE in Hijriyah Calendar, A

$$
A=(272,461.5 \text { days }) /(10,631 \text { days })=25 \text { cycles and } 6,686.5 \text { days }
$$

To calculate number of years in the Hijriyah Calendar $B$,

$$
\mathrm{B}=25 \text { cycles } \mathrm{x} 30 \text { years } / \text { cycle }=750 \mathrm{H}
$$

To calculate the month and date in the Hijriyah Calendar $C$,

$$
\begin{gathered}
\mathrm{C}=6.686,5: 10.631 / 30=18 \mathrm{H} \text { and } 307.9 \text { days } \approx 18 \mathrm{H} \text { and } 308 \text { days } \\
308 \text { days }=10 \text { months and } 13 \text { days }
\end{gathered}
$$

From $B$ and $C$, to calculate the year number $D$,

$$
\mathrm{D}=750+18=768 \mathrm{H}
$$

From $C$ to calculate the month $E$,

$$
\mathrm{E}=10+1=11=\text { Month of Dzulqo'dah }
$$

To calculate year number in the Javanese Calendar $F$,

$$
\mathrm{F}=\mathrm{D}+512=1280 \mathrm{Java}
$$

Thus, July $1^{\text {st }}, 1368 \mathrm{CE}$ corresponds to Dzulqo'dah, $13^{\text {th }}, 768 \mathrm{H}$ and Sela, $13^{\text {th }}, 1280$ Java. Then we calculate the conversion for all months in $1368 \mathrm{CE}$ and compare it with the two other references, i.e. Espenak and NASA. The results are in Table 2 below.

Table 2. Date Conversion from Julian Calendar to Hijriyah Calendar and Javanese Calendar for 1368 CE with Hisab Urfi Approach

\begin{tabular}{|c|c|c|c|c|c|c|c|c|c|}
\hline \multicolumn{4}{|c|}{ Julian Calendar (1368 CE) } & \multicolumn{3}{c|}{ Hijriyah Calendar } & \multicolumn{3}{c|}{ Javanese Calendar } \\
\cline { 1 - 8 } Literature & Month & Date & $\begin{array}{c}\text { UTC } \\
+\mathbf{0 7}\end{array}$ & Year & Month & Date & Year & Month & Date \\
\cline { 1 - 8 } Espenak & \multirow{2}{*}{ Jan } & 6 & $03: 26$ & 768 & $\begin{array}{c}\text { Jumadil } \\
\text { Awal }\end{array}$ & 13 & 1280 & $\begin{array}{c}\text { Jumadil } \\
\text { Awal }\end{array}$ & 13 \\
\cline { 3 - 10 } & NASA & - & - & - & - & - & - & - & - \\
\hline
\end{tabular}




\begin{tabular}{|c|c|c|c|c|c|c|c|c|c|}
\hline \multicolumn{4}{|c|}{ Julian Calendar (1368 CE) } & \multicolumn{3}{|c|}{ Hijriyah Calendar } & \multicolumn{3}{|c|}{ Javanese Calendar } \\
\hline Literature & Month & Date & $\begin{array}{l}\text { UTC } \\
+07\end{array}$ & Year & Month & Date & Year & Month & Date \\
\hline Stellarium & & 6 & $23: 00$ & 768 & $\begin{array}{c}\text { Jumadil } \\
\text { Awal }\end{array}$ & 13 & 1280 & $\begin{array}{c}\text { Jumadil } \\
\text { Awal }\end{array}$ & 13 \\
\hline Espenak & \multirow{3}{*}{$\mathrm{Feb}$} & 4 & $22: 39$ & 768 & $\begin{array}{c}\text { Jumadil } \\
\text { Akhir }\end{array}$ & 12 & 1280 & Jumadilakir & 12 \\
\hline NASA & & - & - & - & - & - & - & - & - \\
\hline Stellarium & & 5 & 23:00 & 768 & $\begin{array}{c}\text { Jumadil } \\
\text { Akhir }\end{array}$ & 13 & 1280 & Jumadilakir & 13 \\
\hline Espenak & \multirow{3}{*}{ Mar } & 5 & $15: 22$ & 768 & Rajab & 13 & 1280 & Rejeb & 13 \\
\hline NASA & & - & - & - & - & - & - & - & - \\
\hline Stellarium & & 5 & 23:00 & 768 & Rajab & 13 & 1280 & Rejeb & 13 \\
\hline Espenak & \multirow{3}{*}{ Apr } & 4 & $04: 54$ & 768 & Syakban & 13 & 1280 & Ruwah & 13 \\
\hline NASA & & - & - & - & - & - & - & - & - \\
\hline Stellarium & & 4 & 23:00 & 768 & Syakban & 13 & 1280 & Ruwah & 13 \\
\hline Espenak & \multirow{3}{*}{ May } & 3 & $15: 36$ & 768 & Ramadhan & 13 & 1280 & Pasa & 13 \\
\hline NASA & & - & - & - & - & - & - & - & - \\
\hline Stellarium & & 3 & $23: 00$ & 768 & Ramadhan & 13 & 1280 & Pasa & 13 \\
\hline Espenak & \multirow{3}{*}{ Jun } & 2 & 00:18 & 768 & Syawal & 13 & 1280 & Sawal & 13 \\
\hline NASA & & - & - & - & - & - & - & - & - \\
\hline Stellarium & & 2 & 23:00 & 768 & Syawal & 13 & 1280 & Sawal & 13 \\
\hline Espenak & \multirow{3}{*}{$\operatorname{Jul}(1)$} & 1 & 07:49 & 768 & Dzulqo'dah & 13 & 1280 & Sela & 13 \\
\hline NASA & & - & - & - & - & - & - & - & - \\
\hline Stellarium & & 1 & 23:00 & 768 & Dzulqo'dah & 13 & 1280 & Sela & 13 \\
\hline Espenak & \multirow{3}{*}{ Jul (2) } & 30 & 15:01 & 768 & Dzulhijah & 12 & 1280 & Besar & 12 \\
\hline NASA & & - & - & - & - & - & - & - & - \\
\hline Stellarium & & 31 & 23:00 & 768 & Dzulhijah & 13 & 1280 & Besar & 13 \\
\hline Espenak & \multirow{3}{*}{ Agt } & 28 & $22: 43$ & 769 & Muharram & 12 & 1281 & Sura & 12 \\
\hline NASA & & - & - & - & - & - & - & - & - \\
\hline Stellarium & & 29 & 23:00 & 769 & Muharram & 13 & 1281 & Sura & 13 \\
\hline Espenak & \multirow{3}{*}{ Sep } & 27 & 07:54 & 769 & Safar & 12 & 1281 & Sapar & 12 \\
\hline NASA & & - & - & - & - & - & - & - & - \\
\hline Stellarium & & 28 & 23:00 & 769 & Safar & 13 & 1281 & Sapar & 13 \\
\hline Espenak & \multirow{2}{*}{ Oct } & 26 & $19: 28$ & 769 & $\begin{array}{c}\text { Rabi'ul } \\
\text { Awal }\end{array}$ & 12 & 1281 & Mulud & 12 \\
\hline NASA & & - & - & - & - & - & - & - & - \\
\hline
\end{tabular}




\begin{tabular}{|c|c|c|c|c|c|c|c|c|c|}
\hline \multicolumn{4}{|c|}{ Julian Calendar (1368 CE) } & \multicolumn{3}{|c|}{ Hijriyah Calendar } & \multicolumn{3}{|c|}{ Javanese Calendar } \\
\hline Literature & Month & Date & $\begin{array}{l}\text { UTC } \\
+07\end{array}$ & Year & Month & Date & Year & Month & Date \\
\hline Stellarium & & 27 & 23:00 & 769 & $\begin{array}{c}\text { Rabi'ul } \\
\text { Awal }\end{array}$ & 13 & 1281 & Mulud & 13 \\
\hline Espenak & \multirow{3}{*}{ Nov } & 25 & 10:01 & 769 & $\begin{array}{c}\text { Rabi'ul } \\
\text { Akhir }\end{array}$ & 12 & 1281 & $\begin{array}{l}\text { Bakda } \\
\text { Mulud }\end{array}$ & 12 \\
\hline NASA & & - & - & - & - & - & - & - & - \\
\hline Stellarium & & 26 & 23:00 & 769 & $\begin{array}{l}\text { Rabi'ul } \\
\text { Akhir }\end{array}$ & 13 & 1281 & $\begin{array}{l}\text { Bakda } \\
\text { Mulud }\end{array}$ & 13 \\
\hline Espenak & \multirow{3}{*}{ Des } & 25 & 03:17 & 769 & $\begin{array}{c}\text { Jumadil } \\
\text { Awal }\end{array}$ & 13 & 1281 & $\begin{array}{c}\text { Jumadil } \\
\text { Awal } \\
\end{array}$ & 13 \\
\hline NASA & & - & - & - & - & - & - & - & - \\
\hline Stellarium & & 25 & 23:00 & 769 & $\begin{array}{c}\text { Jumadil } \\
\text { Awal }\end{array}$ & 13 & 1281 & $\begin{array}{c}\text { Jumadil } \\
\text { Awal }\end{array}$ & 13 \\
\hline
\end{tabular}

Note: Italic means there is inequality of date between those two references.

\subsubsection{Date Conversion Using A 120-Year Correction between Hijriyah and Javanese Calendar}

To conduct this conversion, we use again (1) then treat it in the framework of the Javanese Calendar. The details are as follows:

Number of days between July $16^{\text {th }}, 622$ CE and July $1^{\text {st }}, 1368$ CE in Javanese Calendar $G$,

$$
\mathrm{G}=272,461.5 / 2,835=96 \text { cycles and } 301.5 \text { days }
$$

To calculate number of years in the Javanese Calendar that has passed $H$,

$$
\mathrm{H}=96 \text { cycles } \mathrm{x} 8 \text { years } / \text { cycle }=768 \mathrm{Java}
$$

Using 512 as the difference in the number of years between the Hijriyah and Javanese Calendar, the actual Javanese year number $J$,

$$
\mathrm{J}=\mathrm{H}+512=1280 \mathrm{Java}
$$

To calculate the month and date in Javanese Calendar $K$,

$$
\mathrm{K}=301.5 \text { days }=10 \text { months and } 6.5 \text { days } \approx 10 \text { months and } 7 \text { days }
$$

From $K$, number of month $L$,

$$
\mathrm{L}=10+1=11=\text { Sela }
$$

With a 120 -year correction $N$, we obtain,

$$
\mathrm{N}=7+6=13
$$

Thus July $1^{\text {st }}, 1368$ CE corresponds to Sela $13^{\text {th }}, 1280$ Java. Then we calculate the conversion for all months in $1368 \mathrm{CE}$ in the framework of the Javanese Calendar and compare it with the two other references, i.e. Espenak and NASA. The results are shown in the Table 3. 
Table 3. Date Conversion from Julian Calendar to Javanese Calendar for 1368 CE with a 120 -Year Correction

\begin{tabular}{|c|c|c|c|c|c|c|}
\hline \multicolumn{4}{|c|}{ Julian Calendar (1368 CE) } & \multicolumn{3}{|c|}{ Javanese Calendar } \\
\hline Literature & Month & Date & UTC $+\mathbf{0 7}$ & Year & Month & Date \\
\hline Espenak & \multirow{3}{*}{ Jan } & 6 & $3: 26$ & 1280 & Jumadil Awal & 13 \\
\hline NASA & & - & - & - & - & - \\
\hline Stellarium & & 6 & 23:00 & 1280 & Jumadil Awal & 13 \\
\hline Espenak & \multirow{3}{*}{$\mathrm{Feb}$} & 4 & $22: 39$ & 1280 & Jumadilakir & 12 \\
\hline NASA & & - & - & - & - & - \\
\hline Stellarium & & 5 & $23: 00$ & 1280 & Jumadilakir & 13 \\
\hline Espenak & \multirow{3}{*}{ Mar } & 5 & $15: 22$ & 1280 & Rejeb & 13 \\
\hline NASA & & - & - & - & - & - \\
\hline Stellarium & & 5 & 23:00 & 1280 & Rejeb & 13 \\
\hline Espenak & \multirow{3}{*}{ Apr } & 4 & $4: 54$ & 1280 & Ruwah & 13 \\
\hline NASA & & - & - & - & - & - \\
\hline Stellarium & & 4 & 23:00 & 1280 & Ruwah & 13 \\
\hline Espenak & \multirow{3}{*}{ May } & 3 & $15: 36$ & 1280 & Pasa & 13 \\
\hline NASA & & - & - & - & - & - \\
\hline Stellarium & & 3 & 23:00 & 1280 & Pasa & 13 \\
\hline Espenak & \multirow{3}{*}{ Jun } & 2 & $0: 18$ & 1280 & Sawal & 13 \\
\hline NASA & & - & - & - & - & - \\
\hline Stellarium & & 2 & 23:00 & 1280 & Sawal & 13 \\
\hline Espenak & \multirow{3}{*}{ Jul (1) } & 1 & $7: 49$ & 1280 & Sela & 13 \\
\hline NASA & & - & - & - & - & - \\
\hline Stellarium & & 1 & $23: 00$ & 1280 & Sela & 13 \\
\hline Espenak & \multirow{3}{*}{ Jul (2) } & 30 & $15: 01$ & 1280 & Besar & 12 \\
\hline NASA & & - & - & - & - & - \\
\hline Stellarium & & 31 & 23:00 & 1280 & Besar & 13 \\
\hline Espenak & \multirow{3}{*}{$A g t$} & 28 & $22: 43$ & 1281 & Sura & 12 \\
\hline NASA & & - & - & - & - & - \\
\hline Stellarium & & 29 & 23:00 & 1281 & Sura & 13 \\
\hline Espenak & \multirow{3}{*}{ Sep } & 27 & $7: 54$ & 1281 & Sapar & 12 \\
\hline NASA & & - & - & - & - & - \\
\hline Stellarium & & 28 & $23: 00$ & 1281 & Sapar & 13 \\
\hline
\end{tabular}




\begin{tabular}{|c|c|c|c|c|c|c|}
\hline \multicolumn{4}{|c|}{ Julian Calendar (1368 CE) } & \multicolumn{3}{|c|}{ Javanese Calendar } \\
\hline Literature & Month & Date & UTC $+\mathbf{0 7}$ & Year & Month & Date \\
\hline Espenak & \multirow{3}{*}{ Oct } & 26 & $19: 28$ & 1281 & Mulud & 12 \\
\hline NASA & & - & - & - & - & - \\
\hline Stellarium & & 27 & $23: 00$ & 1281 & Mulud & 13 \\
\hline Espenak & \multirow{3}{*}{ Nov } & 25 & $10: 01$ & 1281 & Bakda Mulud & 12 \\
\hline NASA & & - & - & - & - & - \\
\hline Stellarium & & 26 & 23:00 & 1281 & Bakda Mulud & 13 \\
\hline Espenak & \multirow{3}{*}{ Des } & 25 & $3: 17$ & 1281 & Jumadilawal & 13 \\
\hline NASA & & - & - & - & - & - \\
\hline Stellarium & & 25 & $23: 00$ & 1281 & Jumadilawal & 13 \\
\hline
\end{tabular}

Note: Italic means there is inequality of date between those two references.

\subsubsection{Date Conversion from Solar to Javanese Calendar for 2018 CE}

To calculate this conversion, we take into account that the Western Calendar transitioned from the Julian Calendar to the Gregorian Calendar on October $5^{\text {th }}, 1582 \mathrm{CE}$. Using the same conversion as the previous section, we get for the last day of the Julian Calendar,

$$
\text { October } 4^{\text {th }}, 1582 \mathrm{CE}=\text { Ramadhan } 16^{\text {th }}, 990 \mathrm{H}=\text { Pasa } 16^{\text {th }}, 1502 \text { Java. }
$$

We know that the next day is Pasa $17^{\text {th }}, 1502$ Java, but in the Gregorian Calendar the next day is October $15^{\text {th }}, 1582 \mathrm{CE}$. For this reason, we choose new reference dates for the conversion, indicated in Diagram 2.

Diagram 2. The Calculation Scheme

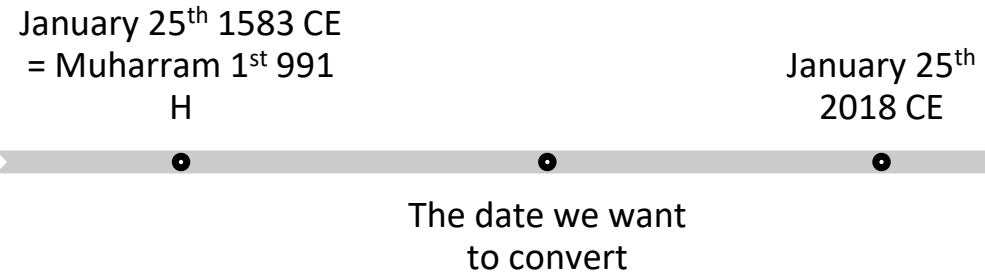

As we did for the previous conversion, we calculate for all months in $2018 \mathrm{CE}$ in the framework of the Javanese Calendar using a 120-year correction and compare it with the two other references. We can see the result in the Table 4 below.

Table 4. Date Conversion from Gregorian Calendar to Hijriyah Calendar and Javanese Calendar in $2018 \mathrm{CE}$

\begin{tabular}{|c|c|c|c|c|c|c|c|c|c|}
\hline \multicolumn{4}{|c|}{ Gregorian Calendar (2018 CE) } & \multicolumn{3}{c|}{ Hijriyah Calendar } & \multicolumn{3}{c|}{ Javanese Calendar } \\
\hline Literature & Month & Date & $\begin{array}{c}\text { UTC } \\
+\mathbf{0 7}\end{array}$ & Year & Month & Date & Year & Month & Date \\
\hline Espenak & $\begin{array}{c}\text { Jan } \\
(1)\end{array}$ & 2 & $9: 24$ & 1439 & $\begin{array}{c}\text { Rabi'ul } \\
\text { Akhir }\end{array}$ & 13 & 1951 & $\begin{array}{c}\text { Bakda } \\
\text { Mulud }\end{array}$ & 12 \\
\hline
\end{tabular}




\begin{tabular}{|c|c|c|c|c|c|c|c|c|c|}
\hline \multicolumn{4}{|c|}{ Gregorian Calendar (2018 CE) } & \multicolumn{3}{|c|}{ Hijriyah Calendar } & \multicolumn{3}{|c|}{ Javanese Calendar } \\
\hline Literature & Month & Date & $\begin{array}{l}\text { UTC } \\
+07 \\
\end{array}$ & Year & Month & Date & Year & Month & Date \\
\hline NASA & & 2 & $9: 24$ & 1439 & $\begin{array}{c}\text { Rabi'ul } \\
\text { Akhir }\end{array}$ & 13 & 1951 & $\begin{array}{l}\text { Bakda } \\
\text { Mulud }\end{array}$ & 12 \\
\hline Stellarium & & 2 & 23:00 & 1439 & $\begin{array}{l}\text { Rabi'ul } \\
\text { Akhir }\end{array}$ & 13 & 1951 & $\begin{array}{l}\text { Bakda } \\
\text { Mulud }\end{array}$ & 12 \\
\hline Espenak & \multirow{3}{*}{$\begin{array}{l}\text { Jan } \\
(2)\end{array}$} & 31 & $20: 27$ & 1439 & $\begin{array}{c}\text { Jumadil } \\
\text { Awal }\end{array}$ & 13 & 1951 & $\begin{array}{c}\text { Jumadil } \\
\text { Awal }\end{array}$ & 12 \\
\hline NASA & & 31 & $20: 27$ & 1439 & $\begin{array}{c}\text { Jumadil } \\
\text { Awal }\end{array}$ & 13 & 1951 & $\begin{array}{c}\text { Jumadil } \\
\text { Awal }\end{array}$ & 12 \\
\hline Stellarium & & 31 & 23:00 & 1439 & $\begin{array}{c}\text { Jumadil } \\
\text { Awal }\end{array}$ & 13 & 1951 & $\begin{array}{c}\text { Jumadil } \\
\text { Awal }\end{array}$ & 12 \\
\hline Espenak & \multirow{3}{*}{$\operatorname{Mar}(1)$} & 2 & $7: 51$ & 1439 & $\begin{array}{c}\text { Jumadil } \\
\text { Akhir }\end{array}$ & 14 & 1951 & Jumadilakir & 13 \\
\hline NASA & & 2 & $7: 51$ & 1439 & $\begin{array}{c}\text { Jumadil } \\
\text { Akhir }\end{array}$ & 14 & 1951 & Jumadilakir & 13 \\
\hline Stellarium & & 1 & $23: 00$ & 1439 & $\begin{array}{c}\text { Jumadil } \\
\text { Akhir }\end{array}$ & 13 & 1951 & Jumadilakir & 12 \\
\hline Espenak & \multirow{3}{*}{$\operatorname{Mar}(2)$} & 31 & $19: 37$ & 1439 & Rajab & 13 & 1951 & Rejeb & 12 \\
\hline NASA & & 31 & $19: 37$ & 1439 & Rajab & 13 & 1951 & Rejeb & 12 \\
\hline Stellarium & & 31 & $23: 00$ & 1439 & Rajab & 13 & 1951 & Rejeb & 12 \\
\hline Espenak & \multirow{3}{*}{ Apr } & 30 & $7: 58$ & 1439 & Syakban & 13 & 1951 & Ruwah & 12 \\
\hline NASA & & 30 & $7: 58$ & 1439 & Syakban & 13 & 1951 & Ruwah & 12 \\
\hline Stellarium & & 30 & $23: 00$ & 1439 & Syakban & 13 & 1951 & Ruwah & 12 \\
\hline Espenak & \multirow{3}{*}{ May } & 29 & $21: 20$ & 1439 & Ramadhan & 13 & 1951 & Pasa & 12 \\
\hline NASA & & 29 & $21: 20$ & 1439 & Ramadhan & 13 & 1951 & Pasa & 12 \\
\hline Stellarium & & 29 & $23: 00$ & 1439 & Ramadhan & 13 & 1951 & Pasa & 12 \\
\hline Espenak & \multirow{3}{*}{ Jun } & 28 & $11: 53$ & 1439 & Syawal & 13 & 1951 & Sawal & 12 \\
\hline NASA & & 28 & $11: 53$ & 1439 & Syawal & 13 & 1951 & Sawal & 12 \\
\hline Stellarium & & 28 & 23:00 & 1439 & Syawal & 13 & 1951 & Sawal & 12 \\
\hline Espenak & \multirow{3}{*}{ Jul } & 28 & $3: 21$ & 1439 & Dzulqo'dah & 14 & 1951 & Sela & 13 \\
\hline NASA & & 28 & $3: 21$ & 1439 & Dzulqo'dah & 14 & 1951 & Sela & 13 \\
\hline Stellarium & & 27 & $23: 00$ & 1439 & Dzulqo'dah & 13 & 1951 & Sela & 12 \\
\hline Espenak & \multirow{3}{*}{ Agt } & 26 & $18: 56$ & 1439 & Dzulhijah & 13 & 1951 & Besar & 12 \\
\hline NASA & & 26 & $18: 56$ & 1439 & Dzulhijah & 13 & 1951 & Besar & 12 \\
\hline Stellarium & & 26 & $23: 00$ & 1439 & Dzulhijah & 13 & 1951 & Besar & 12 \\
\hline Espenak & \multirow{3}{*}{ Sep } & 25 & $9: 53$ & 1440 & Muharram & 13 & 1952 & Sura & 12 \\
\hline NASA & & 25 & $9: 53$ & 1440 & Muharram & 13 & 1952 & Sura & 12 \\
\hline Stellarium & & 25 & $23: 00$ & 1440 & Muharram & 13 & 1952 & Sura & 12 \\
\hline Espenak & Oct & 24 & $23: 45$ & 1440 & Safar & 12 & 1952 & Sapar & 11 \\
\hline
\end{tabular}




\begin{tabular}{|c|c|c|c|c|c|c|c|c|c|}
\hline \multicolumn{4}{|c|}{ Gregorian Calendar (2018 CE) } & \multicolumn{3}{|c|}{ Hijriyah Calendar } & \multicolumn{3}{|c|}{ Javanese Calendar } \\
\hline Literature & Month & Date & $\begin{array}{l}\text { UTC } \\
+07\end{array}$ & Year & Month & Date & Year & Month & Date \\
\hline NASA & & 24 & $23: 45$ & 1440 & Safar & 12 & 1952 & Sapar & 11 \\
\hline Stellarium & & 25 & 23:00 & 1440 & Safar & 13 & 1952 & Sapar & 12 \\
\hline Espenak & \multirow{3}{*}{ Nov } & 23 & $12: 39$ & 1440 & $\begin{array}{c}\text { Rabi'ul } \\
\text { Awal }\end{array}$ & 13 & 1952 & Mulud & 12 \\
\hline NASA & & 23 & $12: 39$ & 1440 & $\begin{array}{l}\text { Rabi'ul } \\
\text { Awal }\end{array}$ & 13 & 1952 & Mulud & 12 \\
\hline Stellarium & & 23 & 23:00 & 1440 & $\begin{array}{c}\text { Rabi'ul } \\
\text { Awal }\end{array}$ & 13 & 1952 & Mulud & 12 \\
\hline Espenak & \multirow{3}{*}{ Des } & 23 & $0: 49$ & 1440 & $\begin{array}{l}\text { Rabi'ul } \\
\text { Akhir }\end{array}$ & 13 & 1952 & $\begin{array}{l}\text { Bakda } \\
\text { Mulud }\end{array}$ & 12 \\
\hline NASA & & 23 & $0: 49$ & 1440 & $\begin{array}{l}\text { Rabi'ul } \\
\text { Akhir }\end{array}$ & 13 & 1952 & $\begin{array}{l}\text { Bakda } \\
\text { Mulud }\end{array}$ & 12 \\
\hline Stellarium & & 23 & 23:00 & 1440 & $\begin{array}{c}\text { Rabi'ul } \\
\text { Akhir }\end{array}$ & 13 & 1952 & $\begin{array}{l}\text { Bakda } \\
\text { Mulud }\end{array}$ & 12 \\
\hline
\end{tabular}

Note: Italic means there is inequality of date between those two references.

We find from this table that every date in the Gregorian Calendar that we convert into the Hijriyah and the Javanese Lunar Calendar, there is no same date between the Hijriyah and the Javanese Lunar Calendar even though we have applied the 120-year correction. From Table 4, we find that the Javanese Lunar Calendar is one day slower than the Hijriyah calendar. This invalidity happens since $2010 \mathrm{CE}$, the cause of which is still unknown.

\section{Conclusions}

We conclude that the date of the Malam Opat Belasan ceremony which is always held on the $13^{\text {th }}$ to the night of $14^{\text {th }}$ in every month is correct if the date of the full Moon phase that we choose in Stellarium follows the definition of full Moon phase in the Hijriyah Calendar. Specifically, the Hijriyah definition of the full moon indicates that the full Moon phase occurs on the $13^{\text {rd }}, 14^{\text {th }}$, and $15^{\text {th }}$ day of each lunar month.

However, we also find that the 120 -year correction between the Hijriyah and Javanese Lunar Calendar is invalid since 2010 CE. The Javanese Lunar Calendar is one day slower than Hijriyah calendar. The cause of this is still unknown.

\section{References}

1. S. D. Wiramihardja, Ethnoastronomy: The Sundanese of West Jawa and their Relation to Ethnoastronomy, 68, 25-27 (2013)

2. M. Raharto, Sistem Kalendar: Pengantar Studi Hubungan Kalendar dan Fenomena Astronomi Sistem Bumi, Bulan dan Matahari (2005)

3. I. Hakim, Kalender Jawa dan Sunda (2014)

4. G. Ammarel, L. Tsing, Cultural Production of Skylore in Indonesia Research Get 22072214 doi: 10.1007/978-1-4614-6141-8_236 (2015)

5. G. Ammarel, Sky Calendars of The Indo-Malay Archipelago: Regional Diversity/Local Knowledge 85-104 (2015)

6. S. T. T. Raffles, The History of Java, 2, (3) 
7. C. M. D. Silva, The Spring Full Moon, 475-478 (2004)

8. M. Zeilik, The Ethnoastronomy of The Historic Pueblos, II: Moon Watching, 10, 1-22 (1986)

9. M. Vahia, Ethno Astronomy in India. Ethnoastronomy Awakened in Mae Taeng DistrictStampeding at Global Arena (2017)

10. P. Dahedar, M. Vahia, Fieldwork Techniques in Ethnoastronomy. Ethnoastronomy Awakened in Mae Taeng District-Stampeding at Global Arena (2017)

11. W. Orchiston, Studying The History of Indonesian Astronomy: Future Prospects and Possibilities, 20, (2), 145-154 (2017)

12. Jayusman Wacana Takwim Urfi dalam Penanggalan Islam, 7, 18-30 (2009)

13. G. H. Iskandar, A Notes From Kasepuhan Ciptagelar: Revisiting Pranatamangsa, 1-14 (2016)

14. R. M. R. B. Setiawan, Hitungan Kalender Jawa Menurut Sultan Agung

15. https://ciptagelar.info/events/opat-belasan/ accessed on July $24^{\text {th }} 2018$ at 02:10 p.m.

16. http://www.pikiran-rakyat.com/jawa-barat/2017/03/24/tradisi-ciptagelar-di-sukabumimampu-pertahankan-kampung-adat-397144 accessed on July $24^{\text {th }} 2018$ at 03:07 p.m

17. https://www.kompasiana.com/muhiqaz/54f84d79a33311d25d8b4a0e/keunikanperkampungan-di-lereng-gunung-halimun accessed on July $25^{\text {th }} 2018$ at 07:02 p.m

18. https://gstff.wordpress.com/2016/02/08/menuju-gunung/amp/ accessed on July $27^{\text {th }}$ 2018 at 05:50 p.m. 